Szatai Zsolt József őrnagy - Horváth Tibor alezredes:

\title{
A ROBBANÓSZERKEZETEK FELDERÍTÉSÉNEK TÖRTÉNETE 2. (1951-TŐL NAPJAINKIG)
}

DOI: $\underline{10.35926 / \mathrm{HSZ} .2021 .1 .8}$

ÖSSZEFOGLALÓ: A két részben közölt tanulmányban a robbanószerkezetek és azok felderítésének történetét mutatjuk be. A robbanószerkezetek feltalálásával és későbbi tudatos alkalmazásával jelentősen megváltoztak a hadviselés módszerei. Új eljárásokjelentek meg, amelyek már elképzelhetetlenek voltak ilyen eszközök alkalmazása nélkül. Az egyre nagyobb pusztítóképességü robbanószerkezetek megjelenésével párhuzamosan elötérbe került az azok semlegesítésére való igény is. A szemben álló felek mind nagyobb erőfeszítéseket tettek a robbanószerkezetek felderitésére, azok semlegesitésére és megsemmisitésére. A katonai müveletek befejezését követően a robbanószerkezetek felderítése nem veszített fontosságából, hanem alapvetö feltételként jelent meg, hiszen meg kellett a területet tisztítani a katonai cselekményböl visszamaradt és gyilkos veszélyt rejtő eszközöktől.

KULCSSZAVAK: robbanószerkezet, akna, aknamező, felderítés, mentesítés

\section{BEVEZETÉS}

Az aknák és más robbanásveszélyes eszközök - ideértve a löszereket, robbanószerkezeteket, harcanyagokat, a háború egyéb robbanóanyag-maradványait, valamint a rögtönzött robbanószerkezeteket - a katonai müveletek alatt és azok befejezését követöen is veszélyt jelentenek az egész világon.

A 20. század történelme során az alkalmazott robbanószerkezetek mennyisége és azok változatossága soha nem látott méreteket öltött. ${ }^{1}$ A század második felétől napjainkig a robbanószerkezetek alkalmazásában óriási fejlődés tapasztalható. Mind az alkalmazásuk, mind pedig az ellenük való védekezés eszköztárában megtalálhatóak a legmodernebb technikai eszközök. Az utóbbi évtizedek fontos változása, hogy a robbanószerkezetek jelentette veszély már nemcsak a katonai konfliktusokban jelenik meg, hanem a terrorizmus révén a mindennapi életünk részévé vált. Ebben a megváltozott biztonsági környezetben a robbanószerkezetek felderítése más megközelítésbe került. Az esetek többségében a felderítés már nem kizárólag a katonai gyakorlat szerinti mozgástámogatás részeként vagy a területek megtisztításakor játszik szerepet, hanem preventív céllal egy valószínüsíthető cselekmény

\footnotetext{
1 Horváth Tibor: Magyarország akna- és lőszermentesítésének története. A kezdetek 1944-1948. Müszaki Katonai Közlöny, XXVIII. évf. 2018/1., 68. https://mkk.uni-nke.hu/document/mkk-uni-nke-hu/2018_1_07_ Horvath\%20T_Aknamentesites_MKK.pdf(Letöltés időpontja: 2020.08.08.)
} 
bekövetkezését hivatott meggátolni, például létesítmények védelmében, illetve rendezvények vagy kiemelten fontos személyek biztosításával kapcsolatban. ${ }^{2}$

\section{A HIDEGHÁBORÚ IDŐSZAKÁBAN}

A hidegháború időszakát a szemben álló felek állandó versengése jellemezte, és ennek részét képezte a fegyverkezési verseny is. A versengés technikai és taktikai téren egyaránt folyt. Ez sok új tudományos felfedezést eredményezett, amelyek révén egyre fejlettebb harceszközök jelentek meg, ezzel párhuzamosan azonban a másik oldalon csatasorba álltak az ellenük való védekezés eszközei is. Példaként lehet említeni az interkontinentális ballisztikus rakétákat és az azokat elhárító rendszereket, és természetesen az egyre fejlettebb aknákat és aknakutató eszközöket is.

Hosszú kutatások és kísérletek eredményeként a Szovjetunióban megalkották a hordozható indukciós aknadetektort (IMP³), amelyet 1969-ben a Tomszki Kutatóintézet sorozatgyártásban kezdett gyártani. A készülék tökéletesen megfelelt a katonai alkalmazás követelményeinek, rendkívül egyszerü és megbízható volt, valamint különféle áramforrásokról lehetett müködtetni. Az IMP müszer nagyon hamar közkedvelt lett, különösen azért, mert automatikus hangolással rendelkezett, azaz nem igényelt állandó hangolást, így akár az új müszer kezdeti hangolása elegendő volt a teljes ,életciklusa” alatt. ${ }^{4}$ Az eszközt a Varsói Szerződés minden tagállamában rendszeresítették, a Magyar Néphadsereg is nagy számban rendelkezett vele. ${ }^{5}$ Érdekes tény, hogy a korszerüsített IMP-2 aknakutató müszer még mindig sok államban rendszerben van. A későbbiekben az IMP alternatívájaként egy újabb aknakutató berendezést fejlesztettek ki, amelynek müködési elve teljesen eltért a korábbiaktól. Az új eszköz egy hordozható, rádióhullám-alapú érzékelő (RVM $\left.{ }^{6}\right)$ volt, melynek segítségével a gyalogsági és harckocsi elleni aknák felderítése lehetségessé vált bármilyen felületen vagy talajösszetételnél. ${ }^{7}$ Az aknakutató müszerek fejlesztésével kapcsolatos kísérletek gyakran szokatlan megoldásokat is eredményeztek. Ilyen például a Szovjetunióban 1969-ben rendszeresített közúti indukciós aknakutató berendezés (DIM ${ }^{8}$ ), amelyet általában egy hagyományos terepjáró képességű gépkocsira szereltek, de alkalmazták gyalogsági harcjármüre szerelt változatban is.

Az 1960-as években nemcsak az aknafelderítés gépesítése kezdődött el, hanem a gépi aknatelepítő eszközök kifejlesztése is. A szovjet fejlesztők voltak azok, akik a korábbi egyszerű aknacsúszdák helyett kifejlesztették a PMR-2 és a PMR-3 vontatható aknatelepítőt. Ez utóbbi eszköz már képes volt élesíteni is az aknákat, és az előre beállított 4 vagy 5,5 m

2 Szatai Zsolt József: A fémtartalmú robbanószerkezetek felderítéséhez alkalmazott technikai eszközök. Müszaki Katonai Közlöny, 29. évf. 2019/1., 122. http://real.mtak.hu/104129/1/mkk_2019_1_10.pdf (Letöltés időpontja: 2020. 08. 08.)

3 ИМП, Индукционный Миноискатель Переносной.

4 Павел Провин: История создания металлоискателей: отечественное развитие. Часть 3. 22. 05. 2017. https:// www.mdregion.ru/o-kladoiskatelstve/28-rasskazi-kladoiskatelstvo/3475-istoria-sozdania-metalloiskateleichast-3.html (Letöltés időpontja: 2020. 04. 16.)

5 Bucsák Mihály et al.: 70 év az életveszély árnyékában. A magyar tủzszerész- és aknakutató alakulatok története 1945-2015. Zrínyi Kiadó, Budapest, 2015, 71.

6 РВМ, Радиоволновой Миноискатель.

7 Провин: і. m.

8 дИМ, Дорожный Индукционный Миноискатель. 


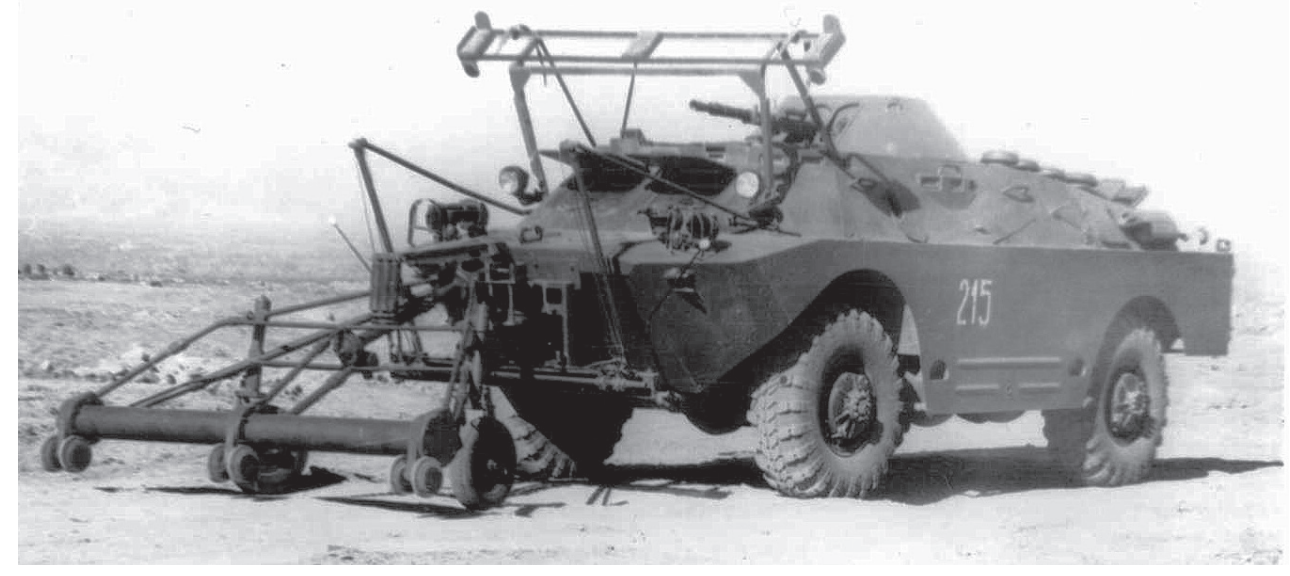

1. ábra Indukciós aknakutató egység BRDM-2 harcjármüre szerelve ${ }^{9}$

távolságban azt a föld felszínére vagy a föld alá telepíteni. ${ }^{10}$ Hasonló eszközöket fejlesztettek ki a világ más országaiban is. Ebben az időszakban az Amerikai Egyesült Államok és a Szovjetunió gyakran adott el fegyvereket egy harmadik országnak, vagy támogattak egyegy országban egymással szemben álló csoportokat, hogy kipróbálják fegyverrendszereik hatékonyságát, majd a tapasztalatokat felhasználva továbbfejlesszék azokat. Minderre jó példa az 1955-1975 között lezajlott vietnámi háború.

A vietnámi háború alapjaiban új környezetet teremtett a robbanószerkezetek alkalmazása és azok felderítése terén. Új eljárásrendek jelentek meg, és megváltozott a hadviselés jellege. A harcok egy arcvonal nélküli hadszíntéren folytak, és azokat az aszimmetria jellemezte. A korábban az indokínai háborúban (1946-1954) a francia gyarmati hadsereggel szemben eredményesen alkalmazott eljárásokat a Vietkong ${ }^{11}$ elkezdte ismét alkalmazni, illetve tovább is fejlesztette azokat. Nem telepítettek összefüggő aknamezőket a területek lezárása érdekében, helyette inkább kisebb aknacsoportokat vagy meglepőaknákat, booby trapeket ${ }^{12}$ alkalmaztak, melyek illeszkedtek az amerikai csapatok fö mozgási útvonalaihoz. A háború első hónapjaiban az amerikai tengerészgyalogság veszteségeinek 65-75\%-át az aknák és a booby trapek okozták. ${ }^{13}$

A booby trap egy rögtönzött módon elöállított sajátos robbanórendszer. Telepítésének fő célja a bizonytalanság és a félelem kiváltása az ellenségben, illetve a társadalom egyes csoportjaiban. Az ilyen robbanócsapdák alkalmazása - ellentétben a terrorszervezetek által

${ }_{9}$ DIM na BRDM2. https://www.mycity-military.com/slika.php?slika=192952_162477311_DIM\%20na\%20 BRDM2.jpg (Letöltés időpontja: 2020. 04. 12.)

${ }^{10}$ Lukács László: Kis akna történelem. Nemzetvédelmi Egyetemi Közlemények, 6. évf. 2002/3., 34.

${ }^{11}$ A Dél-vietnámi Nemzeti Felszabadítási Front közismert megnevezése.

${ }^{12}$ Szakirodalomban gyakran használt megnevezés meglepőaknára, rögtönzött robbanószerkezetre, amelyet általában az áldozat hoz múködésbe.

${ }^{13}$ FMFRP 12-43, Professional Knowledge Gained from Operational Experience in Vietnam,1969, Special Issue, Mines and Boobytraps. Department of the Navy, Headquarters United States Marine Corps, Washington DC., Section I, 20. 07. 1989., 1.https://fdocuments.in/download/?url=ele7afa8cc6f80e3686134ef9fb85420461bc7 9b935935d8b72b5ff63443bf64b2235a042c643df0280bdf71b64cd47a6d58c9e87a86a5b79568c0c85bfc0127B Uzj5jb+Xhc/Em9g8FumPQKzwe3L3hY5ZRxB2C7V2ibrU0X/BDx0Z5Lcuc+ksaB+jMjdrBlo16bjPMXCS8 $w W 2 g==$ (Letöltés időpontja: 2020. 08. 09.) 
készített robbanószerkezetekkel - nem egy meghatározott személy ellen, hanem inkább csoportok tagjai ellen irányul. ${ }^{14}$ Általában húzásra vagy teherelvételre müködő gyújtószerkezettel szerelik, szabvány katonai eszközök vagy házilag előállított szükséganyagok felhasználásával. „A meglepöakna lehet bármilyen eszköz vagy anyag, amelynek az a rendeltetése, úgy van megkonstruálva, vagy úgy van összeszerelve, hogy váratlanul müködésbe lépve halált vagy sérülést okozzon, amikor egy személy egy nyilvánvalóan veszélytelennek tünö dologgal végez tevékenységet." 15

A robbanószerkezetek alkalmazásának ilyen irányú változása az azok felderítésére irányuló módszerek és az ellenük való védekezés eljárásrendjének megváltozását is eredményezte. A klasszikus robbanószerkezet-felderítést ellentevékenységek komplex rendszere egészítette ki, melyek célja az volt, hogy csökkentsék a Vietkong lehetőségeit a robbanószerkezetek telepítésére, illetve a már telepített eszközök könnyebben felderíthetőek legyenek, ezáltal csökkentsék a veszteségeket. Alapelvként fogalmazták meg, hogy a legjobb védelem a robbanószerkezetek ellen a felkészített és éber katona. ${ }^{16}$

Ez a megközelítés teljesen új alapokra helyezte a robbanószerkezetek felderítését, az már nem kizárólag a müszaki csapatok egyik feladataként jelent meg, hanem minden tengerészgyalogos feladatává vált, természetesen bizonyos mélységig. Az egyéni felkészítés azokat az ismereteket foglalta magában, melyek segítségével a katonák felismerték a terepen az aknák és a booby trapek telepítésére utaló jeleket, melyek következtében új magatartásformák összességét vezették be, azok alkalmazásával pedig a veszteségek csökkenthetőek voltak. Ilyen volt a kötelező sisak- és mellényhasználat, a nagyobb tér- vagy távköz tartása a gyalogos járör tagjai között, vagy a gépjármüvek homokzsákkal történő megerősítése. Alapvető szabályként bevezették az emléktárgyak gyüjtésének tilalmát, hiszen a booby trapek telepítésének fő szempontjai a kíváncsiság felkeltése, a vizuális ingerkeltés és a „csalétekelv” voltak, azaz bármelyik emléktárgy vagy látszólag hátrahagyott eszköz lehetett meglepőakna is. ${ }^{17}$

A robbanószerkezetek elleni küzdelem másik fő iránya a lehetséges telepítő erők felderítése, és így a robbanószerkezetek elhelyezésének megakadályozása volt. Ez a feladat kellőképpen nehéz volt, hiszen a felkelők otthonosan mozogtak a dzsungelben. A felderítés érdekében az amerikai csapatok sürítették a járőrözést és a helyi falvak ellenörzését, továbbá hordozható szárazföldi mozgásérzékelő radarokat alkalmaztak, de sok esetben helyi informátorokra is támaszkodtak.

Az egyébként is nehéz terepen folytatott mủveleteket megnehezítette, hogy az ellenállók előszeretettel alkalmaztak botlódrótos indítású robbanószerkezeteket, melyek felderítése meglehetősen nehéz volt a magas aljnövényzetben. Ennek a megkönnyítésére kutyákat használtak. A keresőkutyák derítették fel a robbanószerkezeteket, de sok esetben jelzést tettek, amikor érzékelték a telepítő szagmaradványait vagy a botlódrótot. Az alkalmazásuk

\footnotetext{
${ }^{14}$ Mueller Othmár: Korszerü szükséganyagból készített robbanószerkezetek alkalmazásának és hatástalanításának sajátosságai, a jövőbeni fejlesztés irányai a terrorizmus figyelembevételével. Kandidátusi értekezés, 1995.

15 1997. évi CXXXIII. törvény a „Mértéktelen sérülést okozónak vagy megkülönböztetés nélkül hatónak tekinthető egyes hagyományos fegyverek alkalmazásának betiltásáról, illetőleg korlátozásáról” szóló egyezmény és a hozzá csatolt jegyzőkönyvek kihirdetéséről rendelkező 1984. évi 2. törvényerejű rendelet módosításáról és kiegészítéséröl, 2. cikk, 4. Kihirdetve: 1997. XII. 10. https://net.jogtar.hu/getpdf?docid=99700133.TV\&targetdate=2007 0701\&printTitle=1997.+\%C3\%A9vi+CXXXIII.+t\%C3\%B6rv\%C3\%A9ny\&referer=http\%3A//net.jogtar.hu/jr/ gen/hjegy_doc.cgi\%3Fdocid\%3DA1200100.TV (Letöltés időpontja: 2020. 06. 10.)

16 FMFRP 12-43: i. m. 2.

17 FMFRP 12-43: i. m. 15.
} 
hatékonyságát mutatja, hogy a hadszíntéren elvesztett kutyák mindössze 6\%-a pusztult el akna vagy meglepőakna robbanásának következtében. ${ }^{18}$

Az ilyen módon előtalált robbanószerkezetek hatástalanítása továbbra is a müszaki vagy tűzszerészalegységek feladata volt. Ezek az alegységek feleltek a csapatok előtti területek biztonságossá tételéért, az ott elhelyezett robbanószerkezetek felderítéséért, azok hatástalanításáért és biztonságos átjáró létesítéséért a területen. A szakfeladathoz általában a kézi aknamentesítéshez alkalmazott utásztőr és dobókörte, illetve aknakifordító horog mellett indukciós aknakutató eszközöket is alkalmaztak. Az AN/PRS-3 indukciós aknakutató müszer mellett használták az AN/PRS-4 müszert is, de mindkettőnek azonos hiányosságai voltak. Sok esetben jelzést adtak kis fémszennyezettségre is, ami lehetett egy repeszdarab vagy akár egy jelzőrakéta burkolata, de jelezték a müszerek a talajban lévő vastagabb gyökereket vagy nagyobb talajegyenetlenségeket is. ${ }^{19}$ A mentesítést végző szakcsapatoknak sok esetben nem volt elég képességük a robbanószerkezetek hatástalanításához, így gyakran a szennyezett területeket szalaggal kerítették körbe, és azt egyértelmű táblákkal jelölték meg, így jelezve a járőrök számára a veszélyes területeket.

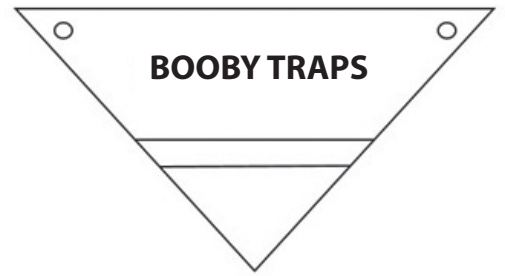

2. ábra Meglepöaknákkal szennyezett terület jelzése (Szerkesztette Szatai Zsolt József az FM 5-31 alapján)

Ezt a megoldást a későbbiekben más müveleti területeken is alkalmazták, és ha a müvelet jellege és dinamikája megengedte, akkor a mentesítés csak a katonai müveletek befejezése után kezdődött meg. De elöfordult az is - az aknaprobléma egyik sajátosan érdekes megközelítéseként, egyben különleges megoldási lehetőségként -, hogy a sérülések megakadályozása érdekében bekerítették és megjelölték a veszélyes területeket, de azokat a későbbiekben sem mentesítették. Ezt a megoldást például az Egyesült Királyság alkalmazta a Falkland-szigeteken, mivel az aknák mentesítése túl nagy erő- és eszközráfordítással járt volna, szemben annak gazdasági hasznával. Amikor 1982-ben az argentin erők megtámadták a Falkland-szigeteket, az Egyesült Királyság tengerentúli területét, nagyságrendileg 30 ezer aknát telepítettek védelmi céllal 146 különböző aknamezőben. ${ }^{20}$

A brit és argentin müszaki csapatok a brit győzelmet követő hetekben megkezdték a területek kézi aknamentesítését, de a mentesítés közbeni halálesetek és súlyos sérülések miatt azt néhány hét múlva leállították. Később a kézi felderítés és mentesítés kiváltására aknakereső kutyákat és speciális technikai eszközöket vetettek be, de a szélsőséges időjárás miatt azok használata nem bizonyult sikeresnek. Összességében az aknák közel 70\%-át eltávolították, de tekintettel arra, hogy a még nem mentesített területek szociális és gazdasági hatása elhanyagolható, a további müveletek folytatása bizonytalanná vált. ${ }^{21}$

A 20. század második felének egyik legnagyobb mennyiségü hadianyag-felhasználása kétségtelenül a Szovjetunió 1979-1989 közötti afganisztáni beavatkozásához köthető. A háború tíz éve alatt a szovjetek szinte a teljes fegyvertárukat felvonultatták a siker elérése érdekében,

\footnotetext{
${ }_{18}$ Uo. 14.

19 FM 5-31 - Booby Traps. Department of the Army, Washington D.C., 14. 09. 1965., 120. http://everyspec.com/ ARMY/FM-Field-Manual/FM_5-31_13829/(Letöltés időpontja: 2020. 08. 09.)

${ }^{20}$ Landmine Monitor Report 1999, Toward a mine-free world. Human Right Watch, New York, $1999,697$.

${ }^{21}$ Falkland's Demining Project fourth phase draws to a close. MercoPress, 24. 02. 2016. https://en.mercopress. com/2016/02/24/falkland-s-demining-project-fourth-phase-draws-to-a-close (Letöltés időpontja: 2020. 03. 27.)
} 
míg az afgán ellenállókat a mögöttük álló amerikaiak szintén minden lehetséges eszközzel támogatták. A műveletek közben milliós nagyságrendben telepítettek aknákat a talajszint alá, és a távaknásító rendszerek lehetőségeit kihasználva a talaj felszínére is. Az aknák mellett a szovjet erők megszámlálhatatlan mennyiségủ kazettás bombát szórtak az ellenállók feltételezett állásaira és körleteire, míg azok a vietnámihoz hasonló módszerekkel meglepőaknákat telepítettek a szovjetek ellen. A veszélyes hadianyagok felderítése és mentesítése a műveletek biztosítása érdekében folyamatos volt, alkalmazva a kézi, a müszeres és a gépi lehetőségeket. A bevetett hadianyagok mennyiségéhez képest azonban jelentéktelen számú eszközt, illetve szennyezett területet mentesítettek.

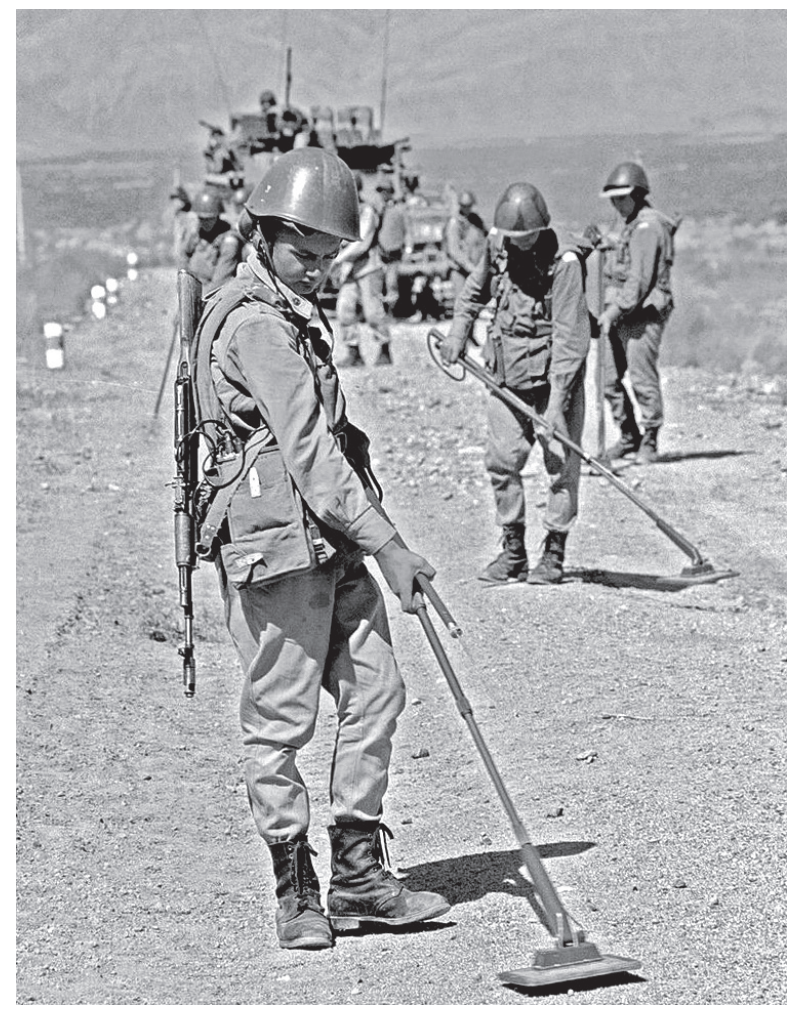

3. ábra Szovjet katonák aknamentesités közben Afganisztánban 1980-ban²2

Az Afganisztán elleni szovjet intervencióhoz szorosan kapcsolódik a humanitárius aknamentesítés létrejötte is. A szovjet csapatok kivonulásának kezdetekor, 1988 októberében az Amerikai Egyesült Államok kollektív fellépést kezdeményezett az Egyesült Nemzetek Szervezeténél (ENSZ) a háborúból visszamaradt robbanószerkezetek, elsősorban az aknák felderítését és hatástalanítását illetően. Az afganisztáni háborúval közel azonos időben zajló irak-iráni háború (1980-1988) szintén megerösítette a kollektív fellépés szükségességét. Az iráni kormányzat hivatalos jelentései szerint a háború alatt az ország északi határszakaszán

\footnotetext{
22 Афганские фотографии солдат советской армии. Афганистан - как это было (цветные фото). Kollege, 15. 07. 2019. https://kollege.ru/sochineniya/afganskie-fotografii-soldat-sovetskoi-armii-afganistan-kak-eto. html (Letöltés időpontja: 2020. 04. 17.)
} 
közel 16 millió aknát telepítettek. ${ }^{23}$ A határ iraki oldalán sem volt jobb a helyzet, hiszen Irak nemcsak felhasználó, de aknagyártó országnak is számított, így óriási készlet hadianyag állt rendelkezésére. A háború befejezése után az iraki Kurdisztán területén, illetve a kuvaiti határszakasz közelében a hátrahagyott aknák hatására számos baleset történt, amely szintén a figyelem középpontjába helyezte a kollektív aknamentesítés szükségességét. ${ }^{24}$

Az együttes fellépés egy teljesen új korszakot nyitott az aknaprobléma kezelésében, hiszen ezt megelőzően az aknamentesítést kizárólag nemzeti szinten hajtották végre. Az új megközelítés már nem kizárólag katonai feladatként határozta meg az akna- és lőszermentesítést, hanem civil szervezetek részvételét is figyelembe vette. Az erre a feladatra 1988 végén létrejött első szervezet a $\mathrm{HALO}^{25}$ Trust volt, de nem sokkal később megalakult a $\mathrm{MAG}^{26}$ is. Az új megközelítés nem kizárólag csak abban jelentkezett, hogy az aknaprobléma kezelése nem kormányzati szervek részvételével történő kollektív fellépésen alapult, hanem az aknafelderítésen és -mentesítésen túlmenően tartalmazta a sérülések megakadályozására irányuló információs és oktatási feladatokat is. ${ }^{27}$

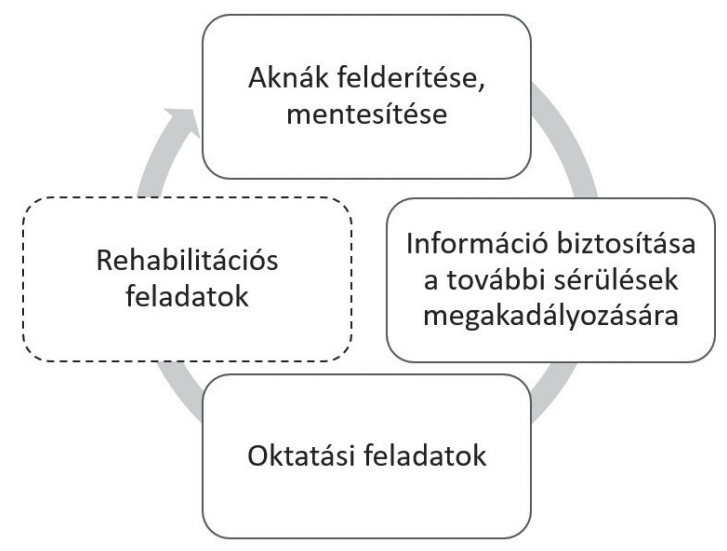

4. ábra A humanitárius aknamentesités feladatrendszere (Szerkesztette Szatai Zsolt József)

A humanitárius aknamentesítés megjelenése új lendületet adott a területhez kapcsolódó technológia fejlődésének, hiszen a kézi aknamentesítés módszerének megtartása mellett egyre nagyobb figyelmet fordítottak a technikai felderítés és hatástalanítás fejlesztésére. Ennek keretében megkezdődött a korábban már katonai konfliktusokban eredményesen alkalmazott buzogányos (flail) aknamentesítő rendszerek fejlesztése. A humanitárius aknamentesítő eszközökkel szemben már nem volt követelmény a szigorú katonai megfelelőség, mint például a páncélvédettség, így méretében lényegesen kisebb és egyszerübb eszközöket tudtak kifejleszteni. A fejlesztőknek azonban figyelembe kellett venni azt, hogy a szerkezet müködési elvéböl adódóan a talaj felső 5-25 cm-es rétegét - ami lényegében a termőréteg - egyszerüen lenyesi. Ez hagyományos katonai alkalmazásban nem probléma, azonban a humanitárius aknamentesítésnél fontos szempont, hiszen a mentesítés után a területet mezőgazdasági termelésbe

\footnotetext{
${ }^{23}$ Landmine Monitor Report 1999: i. m. 885.

24 Uo. 887.

${ }^{25}$ Hazardous Area Life-support Organisation - veszélyes területeken életet mentő szervezet.

${ }^{26}$ Mine Advisory Group - aknákkal kapcsolatban tanácsokat adó csoport.

27 A Guide to Mine Action, 2 ${ }^{\text {nd }}$ edition. Geneva International Centre for Humanitarian Demining, Geneva, $2004,22$.
} 
szeretnék bevonni. ${ }^{28}$ A későbbiekben a kezelőszemélyzet biztonságának fokozása érdekében fontos szempontként jelent meg az eszközök távolról történő irányíthatósága is. Az ilyen eszközöket eredményesen alkalmazták Európában, Ázsiában és Afrikában is. Az afrikai országok közötti kapcsolatokat 1957-től napjainkig a gyarmati függetlenség elnyerése, az önállósodási törekvések, valamint az állandó területviták és polgárháborúk jellemzik. Egyes források szerint a világon jelenleg közel 600-féle különböző akna létezik, és az afrikai kontinensen ezek szinte mindegyike megtalálható, ${ }^{29}$ melyek mentesítése a korábban ismertetett módszerekkel zajlik.

\section{A KÉTPÓLUSÚ VILÁG FELBOMLÁSA UTÁNI ÉVTIZEDEK}

Az 1980-as évek végén bekövetkezett enyhülést, majd a Szovjetunió 1991-ben történt felbomlását követően az Amerikai Egyesült Államok maradt az egyetlen szuperhatalom. Megszünt a hidegháború időszaka, de az első jelentős fegyveres konfliktusra mégsem kellett sokat várni.

1991. január 17-én kezdetét vette a Sivatagi vihar hadmüvelet, vagyis elkezdődött az első öbölháború. A légitámadásokat követően Irak területére behatoló szövetséges csapatok manővereit nemcsak az iraki hadsereg által telepített robbanó müszaki zárak nehezítették, hanem a korábbi iraki-iráni háborúból visszamaradt aknák is, ugyanis a kuvaiti határ közelében számos aknásított terület maradt mentesítetlenül. Az Amerikai Egyesült Államok hivatalos adatai szerint 34 katona vesztette életét és további 143 sebesült meg az öbölháború katonai müveletei alatt aknák, fel nem robbant tüzérségi lövedékek és kazettás bombák robbanásának következtében. Ez az összes veszteség 13\%-a. ${ }^{30}$ A robbanásból adódó sérülések 46\%-át akna, 36\%-át kazettás bomba és $18 \%$-át egyéb katonai eszköz robbanása okozta. ${ }^{31}$

A 42 napig tartó müveletben a fö hangsúlyt a talajfelszín alá telepített aknamezők és a felszínen szórt aknák, illetve fel nem robbant kazettás bombák és egyéb robbanószerkezetek felderítésére és mentesítésére fordították. A szakfeladatokat a korábban már alkalmazott módszerekkel végezték, új eljárást nem vezettek be. A müveletek befejezését követően a mentesítési munkálatokat az ENSZ-szel együttmüködésben lévő nem kormányzati szervezetek vették át, melyek a korábban már eredményes kézi és gépi módszereket alkalmazták.

Az iraki müveletekkel egy időben a Balkánon egy másik konfliktuszóna alakult ki, és megkezdődött a délszláv háborúk időszaka. A korábbi Jugoszlávia hat tagköztársasága eltérő ideig és eltérő mennyiségü hadianyagkészlettel vett részt a harcokban. Ennek az aránytalanságnak az eredményeképpen a hagyományos fegyverek és fegyverrendszerek alkalmazása mellett ismét előtérbe került a meglepőaknák használata. A volt Jugoszlávia területén a szemben álló felek hatalmas mennyiségben telepítettek az áldozat által müködtetett meglepőaknákat, nemcsak a harc megvívása, hanem sok esetben a településekről etnikai alapon elüldözött lakosok visszatelepülésének megakadályozása érdekében is. Az aknák és a fel nem robbant egyéb robbanószerkezetek felderítése és mentesítése a balkáni hadmúveletek

${ }^{28}$ Lukács László: A föld akna-problémája és a megoldás lehetőségei, különös tekintettel a Magyar Honvédség közreműködésének javasolható irányaira III. Müszaki Katonai Közlöny, VIII. évf. 1998/3-4., 6. https://mkk.uninke.hu/document/mkk-uni-nke-hu/1998_3_4\%2002\%20F\%C3\%B6ld\%20aknaprobl\%C3\%A9m\%C3\%A1ja\%20\%20Luk\%C3\%A1cs\%20L.pdf (Letöltés időpontja: 2020. 08. 09.)

${ }^{29}$ Landmines, Explosive Remnants of War and IED Safety Handbook, $3^{\text {rd }}$ edition. United Nations Mine Action Service (UNMAS), New York, 2015, 12. https:/www.unmas.org/sites/default/files/handbook_english.pdf (Letöltés időpontja: 2020. 08. 09.)

${ }^{30}$ GAO-02-1003 U.S. Use of Land Mines in the Persian Gulf War. United States General Accounting Office, Washington, DC, 09. 2002., 15. https://www.gao.gov/assets/240/235830.pdf (Letöltés időpontja: 2020. 08. 09.)

31 Uo. 17. 
során komoly kihívást okozott. Becslések szerint közel egymillió akna (ennek 83\%-a gyalogság, 17\%-a pedig harckocsi elleni) és 500 ezer egyéb robbanószerkezet vagy robbanószerkezet-maradvány volt a müveleti területen. ${ }^{32}$ A terület újjáépítését, a háború alatt elüldözött családok visszatelepülését, illetve a mezőgazdasági területek müvelésének megindítását a robbanószerkezetek jelenléte akadályozta, így azok felderítése és mentesítése elsődleges fontosságúvá vált. Ez a feladat óriási leterheltséget jelentett a szövetséges eröknek, a helyi fegyveres és rendvédelmi szervezeteknek és a nem kormányzati szervezeteknek egyaránt.

A feladatokba bekapcsolódott Magyar Honvédség a második világháború óta először találkozott ilyen volumenű feladatrendszerrel. A horvátországi Okučaniban települt Magyar Müszaki Kontingens hat év alatt 380 müszaki szakfeladatot hajtott végre, melynek részét képezte közel 200 ezer $\mathrm{m}^{2}$ terület tüzszerészeti átvizsgálása, valamint akna- és löszermentesítése. ${ }^{33}$ A nyílt területek mentesítése gépi eszközökkel történt, azonban a lakóházak és mütárgyak környékét vagy a bozótos területeket csak kézi erővel lehetett mentesíteni. A munkálatokat megnehezítette, hogy a délszláv háború alatt számos olyan hagyományos és szórt aknát alkalmaztak, amelyek nem tartalmaztak fémet, így azok felderítése indukciós aknakutató müszerekkel nem volt lehetséges. Szükség volt a szúróbottal történő felderítés gyakorlati módszereinek a megváltoztatására is, ugyanis a korábban alkalmazott eljárásrend szerint a felderítést végző személy úgy használta a szúróbotot, hogy az a talajjal megközelítőleg $45^{\circ}$-os szöget zárt be. Bizonyos gyalogság elleni aknatípusok ${ }^{34}$ azonban kialakításuk révén ilyen behatásra elmüködtek, azzal súlyos sérüléseket vagy halált okoztak. A kidolgozott új eljárásrend alapján a felderítést úgy kellett végrehajtani, hogy a szúróbot és a talaj felszíne nem zárhatott be $30^{\circ}$-nál nagyobb szöget. A változtatás biztonságosnak bizonyult, így ezt a szabályt a későbbi műveletekben is alkalmazták.

A nemzetközi katonai kötelékek nagyarányú létszámkivonását követően a területek aknaés lőszermentesítésének feladatát az adott országok fegyveres erői, illetve nem kormányzati szervek vették át. A felderítés során egyre nagyobb hangsúlyt fektettek az állatokkal támogatott felderítésre. Nagy számban alkalmaztak robbanóanyag- és aknakereső kutyákat, 2017 óta pedig olyan projekteket indítottak, melyek célja innovatív módszerek és technológiák kifejlesztése a talajszint alatt elhelyezett aknák felderítésére. Ennek keretében mézelő méheket is használnak robbanóanyagok felderítéséhez. ${ }^{35}$ A program hároméves kísérleti jelleggel indult el, és a NATO Tudomány a békéért és a biztonságért $\left(\mathrm{SPS}^{36}\right)$ programja keretében valósul meg jelenleg is Horvátországban.

A kétpólusú világrend felbomlása után egy új veszélyforrás is kibontakozott, a terrorizmus. Folyamatos térnyerés jellemzi, és a terroristák céljaik elérése érdekében leggyakrabban robbanószerkezeteket alkalmaztak. A 9/11, vagyis az Amerikai Egyesült Államok

32 Padányi József: A menekültek és hontalanok visszatelepítése Bosznia-Hercegovinába. Hadtudomány, X. évf. 2000/2., 121. http://mhtt.eu/hadtudomany/2000/2_13.html (Letöltés időpontja: 2020. 08. 09.)

${ }^{33}$ Görög István - Padányi József: Az IFOR-SFOR Magyar Müszaki Kontingens 1996-2002. Zrínyi Kiadó, Budapest, 2005, 31 .

${ }^{34}$ Ilyen volt például a jugoszláv gyártmányú PMN-3 romboló hatású gyalogság elleni akna.

35 Biological Method (Bees) for Explosive Detection. NATO E-Library, 17. 03. 2020. https://www.sps-bees4exp. com/ (Letöltés időpontja: 2020. 08. 10.)

${ }^{36}$ Science for Peace and Security Programme. https:/www.nato.int/cps/en/natohq/topics_85373.htm (Letöltés időpontja: 2020. 08. 10.) 
területén 2001. szeptember 11-én végrehajtott terrortámadásokat ${ }^{37}$ követően az ország és szövetségesei 2001. október 7-én megtámadták Afganisztánt, ezzel megkezdődött a világ első terrorizmusellenes háborúja. A beavatkozás célja az országban lévő terrorszervezetek felszámolása és az őket támogató tálib rendszer megdöntése volt. A harcoló felek közötti eltérő erőegyensúly csak a müveletek kezdetén hozott sikert a szövetséges erök számára. Az ellenállók a szovjet intervencióval szemben korábban már eredményesen alkalmazott gerillamódszereket kezdték ismét alkalmazni, és ennek hatására a müveletek jellege teljesen megváltozott. A szemben álló felek eltérő létszáma és a technikai eszközök mennyiségei ellenére a szövetséges erők egyre nagyobb veszteségeket szenvedtek el. E veszteségek fö oka az afganisztáni mủveleti területen ,új eszközként” megjelent, de már 2003-tól Irakban az ellenálló csoportok által a szövetségesekkel szemben előszeretettel alkalmazott rögtönzött robbanószerkezetek $\left(\mathrm{IED}^{38}\right)$ széles körü használata volt. Az új robbanóeszköz megjelenése új felderítési eljárást követelt. A vietnámi és az iraki tapasztalatokból kiindulva a szövetséges erök megállapították, hogy a rögtönzött robbanószerkezetek felderítésére és mentesítésére nem müszaki vagy tűzszerészfeladatként kell tekinteni, hanem azt egy rendszer részeként kell értelmezni. Ennek eredményeképpen létrejött a rögtönzött robbanószerkezetek elleni harc $\left(\mathrm{C}-\mathrm{IED}^{39}\right)$ feladatrendszere.

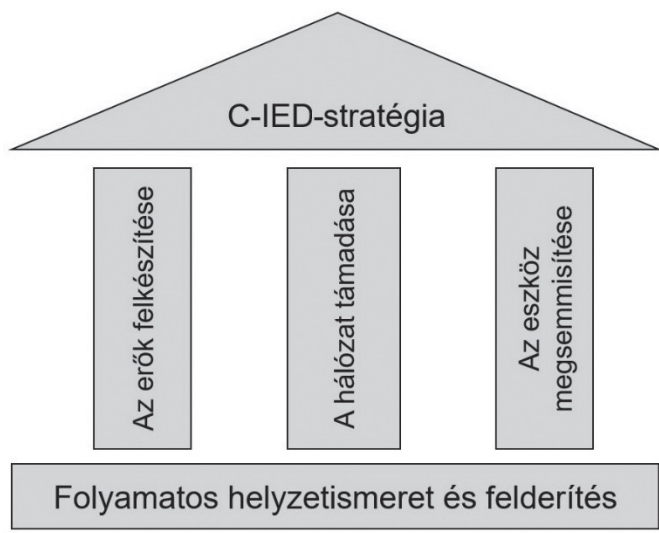

5. ábra A C-IED feladatrendszere (Szerkesztette Szatai Zsolt József az AJP-3.15 Allied Joint Doctrine for Countering Improvised Explosive Devices, NATO Standardization Office, 2018, 1-6 alapján)

A C-IED feladatrendszerének egyik alappillére - vagyis az eszköz megsemmisítése - foglalja magában a robbanószerkezet felderítésére vonatkozó tényleges múszaki szakfeladatokat. A fejlesztések eredményeként a hadszíntéren új technikai eszközök és képességek jelentek meg. Ide sorolhatók az egyre fejlettebb távvezérelt vagy automatizált felderítőrobotok, a robbanóanyag- és robbanószerkezet-maradványt elemző és értékelő mobil laboratóriumok, illetve az útmentesítő-felderítő csoportok. A müveleti területen lévő utak mellett elhelyezett

\footnotetext{
37 2001. szeptember 11-én 8.46-kor az American Airlines 11-es járata a World Trade Center északi tornyába ütközött, majd 9.03-kor a United Airlines 175-ös járata becsapódott a déli toronyba. Az American Airlines 77-es járata 09.37kor a Pentagon épületébe, a United Airlines 93-as járata pedig a pennsylvaniai Shanksville közelében a földbe fúródott.

${ }^{38}$ Improvised Explosive Device.

${ }^{39}$ Counter-Improvised Explosive Device.
} 
robbanószerkezetek nagy veszteségeket okoztak a szövetséges erőknek. ${ }^{40}$ Ezeket az eszközöket vagy az áldozat által múködtetett eszközként, vagy megfigyelt eszközként távirányítással hozták működésbe. A koalíciós erők mozgásszabadságának biztosítása érdekében létrehozták az útmentesítő-felderítő csoportokat, melyek alapvető feladata a meghatározott útvonalat fenyegető robbanószerkezetek, robbanásveszélyes és nem robbanásveszélyes akadályok, valamint torlaszok észlelése, felderítése, azonosítása és megjelölése, illetve a robbanószerkezetek hatástalanítása vagy megsemmisítése, ezáltal csökkentve a katonai müveletek kockázatát. ${ }^{41}$

Számos kézikönyv, szabályzat tartalmazza az útmentesítő-felderítő képesség alkalmazott módszereit, de ez valójában egy képességcsomag, melynek gyakorlati alkalmazhatóságát az abban lévő egységek képessége határozza meg. Ennek oka az, hogy az útmentesítő-felderítő képesség harcászati szinten jelenik meg, és a csoport összetétele nemzeti szinten eltérő lehet, tekintettel az alkalmazott technikai eszközök mennyiségére és képességére. ${ }^{42}$ Ezenkívül nemzetenként eltérő lehet a személyi állomány egyéni és kollektív kiképzése, a technikai eszközökre vonatkozó eljárásrend, ami jelentősen befolyásolja a képesség alkalmazását nemzetközi környezetben.

A nemzetenként eltérő összetételből adódóan alapvetően kétféle alkalmazási eljárás különböztethető meg. Az egyik az, amikor a csoport kevésbé felszerelt, többségében kézi aknakutató eszközökkel és/vagy robbanóanyag-kereső kutyákkal van ellátva. Ez az alkalmazási mód nem tesz lehetővé dinamikus végrehajtást, hiszen a robbanószerkezetek felderítésének sebessége alacsonyabb, mint a másik esetben. A másik alkalmazási mód, amikor a csoport technikailag jobban felszerelt. Az ilyen csoportba tartozhatnak olyan speciális felszerelések, mint a páncélozott aknakutató gépkocsi, aknataposó hengerek, talajradarokkal kombinált kamerarendszerek, pilóta nélküli légi jármüvek, illetve buldózerek és földgyaluk.

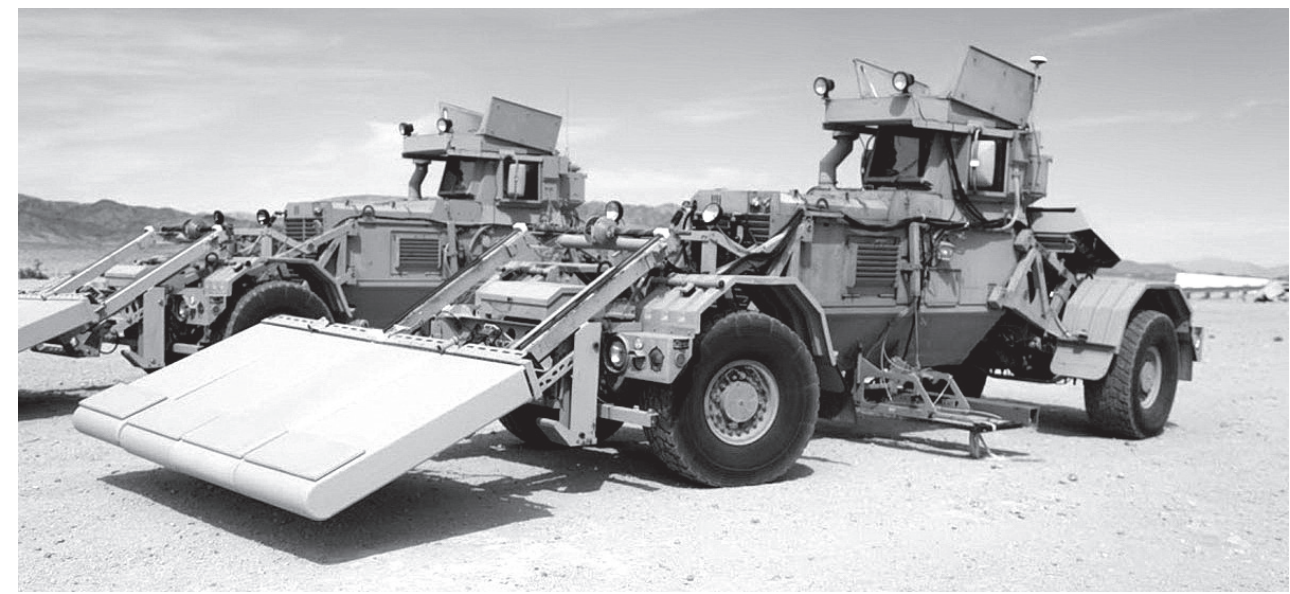

6. ábra Husky páncélozott aknakutató gépjármü ${ }^{43}$

${ }^{40}$ Horváth Tibor: Emergency Cases at Countering Improvised Explosive Devices, and their Potential Management. Revista Academiei Fortelor Terestre / Land Forces Academy Review, XXIV. No. 2, 2019, 97. https://content.sciendo. com/view/journals/raft/24/2/article-p95.xml?lang=de\&result=9\&rskey=PzmED8 (Letöltés időpontja: 2020. 08. 10.)

${ }^{41}$ ATP-3.12.1.3, Allied Tactical Doctrine for Route Clearance, Edition A, Version 1, NATO Standardization Office (NSO), 2016, 1-1.

42 Uo.

${ }^{43}$ Husky Vehicle Mounted Mine Detection System. Military.com. https://www.military.com/equipment/huskyvehicle-mounted-mine-detection-system (Letöltés időpontja: 2020. 04. 11.) 
Ebben az esetben az útvonal akadálymentesítése nagyon alapos és magában foglalja a teljes út akadálymentesítését is. ${ }^{44}$ Mindkét módszernek megvannak az előnyei és a hátrányai, amelyeket figyelembe kell venni a tervezési folyamat során. Megállapítható, hogy a katonai müveletek megváltozott környezete, a robbanószerkezetek alkalmazási eljárásainak változása megváltoztatta a robbanószerkezetek felderítésének rendszerét is. De a megnövekedett veszély nemcsak a hadszíntéren harcoló katonák biztonságát, hanem a hátországban élők mindennapi életét is befolyásolta.

A 2001. szeptember 11-i amerikai események óta a terrorizmus mint veszélyforrás hatást gyakorolt az élet minden területére. Az ezt követő éveket a terrorcselekmények és az arra adott válaszok folyamatos, egymással kölcsönhatásban fejlödő folyamata jellemezte. Különösen igaz ez a légi közlekedéshez kapcsolódó utasbiztonsági szabályokra. A globalizáció korszakában egyre nyitottabb gazdasági térségek jöttek létre, ahol a határellenőrzés eljárásai enyhültek vagy teljesen meg is szüntek. Ez a folyamat megkönnyítette a terrorszervezetek határokon átívelö tevékenységét. A terrorcselekmények a figyelem középpontjába helyezték a robbanóanyagok és a robbanószerkezetek felderítését, de annak átfogó rendszerbe foglalása csak a 2006 augusztusában, az Egyesült Királyságban történt események ${ }^{45}$ után következett be.

A hatékonyság érdekében a robbanóanyagok vagy robbanószerkezetek felderítése esetén új megközelítést alkalmaztak. A feladatban a korábban már érintett fegyveres és rendvédelmi erők mellett megjelent a robbanóanyag-ipar minden szegmense. Az új megközelítés kiemelt fontosságú célja volt, hogy a terrorista szervezeteket és csoportokat a tevékenységük folytatásához szükséges robbanóeszközökhöz jutásban meggátolja. Ezt úgy érték el, hogy szigorúbb és ellenőrzöttebb szabályozást vezettek be a robbanóanyagok gyártása, szállítása, forgalmazása és tárolása terén. A rendszabályokat nemcsak a robbanóanyagokra, de a prekurzorokra ${ }^{46}$ is alkalmazták, hiszen a terrorcselekményekhez alkalmazott robbanóanyagok nagy része ezeknek az anyagoknak a felhasználásával készített házi készítésü robbanóanyag $\left(\mathrm{HME}^{47}\right)$ volt.

A HME veszélyessége abban rejlik, hogy szinte minimális tudásszinttel is nagy hatóerejü és szinte korlátlan mennyiségű robbanóanyagot lehet legyártani. Elöállításuk egyszerü, a robbanóanyag fajtái és azok felhasználási lehetőségei rendkívül változatosak. Ennek megfelelően a robbanóanyagok és a robbanószerkezetek felderítésének lehetséges módszerei is rendkívül széles választékban határozhatók meg. Az utasbiztonság érdekében végzett biztosítási feladatokhoz hatékony és pontos robbanóanyag-felderítési eszközök kifejlesztésére volt szükség. Tekintettel arra, hogy a repülöterekre és a kereskedelmi repülögépek fedélzetére juttatható robbanóanyag mennyisége korlátozott, a nagyobb pusztítás érdekében valószínüsíthető repeszképző anyagok használata. Ennek megfelelően a robbanószerkezetek tartalmazhatnak fémet, az alkalmazás jellegétől függően azonban a fémtartalom eltérő lehet, ami meghatározza annak felderíthetőségét, valamint az arra irányuló módszert és technikai eszközt is. ${ }^{48}$

${ }^{44}$ Szabó Sándor et al.: Az utak, területek akadálymentesítése I. (ROUTE CLEARANCE). Müszaki Katonai Közlöny, XXIV. évf. 2014/3., 20. https://nkerepo.uni-nke.hu/xmlui/bitstream/handle/123456789/13899/Az\%20 utak,\%20ter\%C3\%BCletek\%20akad\%C3\%A1lymentes\%C3\%ADt\%C3\%A9se\%20I..pdf?sequence=1 (Letöltés időpontja: 2020. 08. 09.)

${ }^{45}$ Az MI-6 és a Scotland Yard több hónapos nyomozásának eredményeképpen 2006. augusztus 9-én 24 embert vettek őrizetbe, akik az Egyesült Királyságból Kanadába, illetve az Amerikai Egyesült Államokba induló járatokra akartak folyékony halmazállapotú robbanóanyagot és gyújtófolyadékot felvinni.

${ }^{46}$ Azok a kémiai vegyületek és elemek, amelyek egy vagy több kémiai reakción keresztül robbanóanyag-vegyületté alakíthatók.

${ }^{47}$ Home Made Explosive.

${ }^{48}$ Szatai: i. m. 130. 
A korábban már eredményesen alkalmazott fémérzékelő kapuk, kézi fémkeresők és röntgensugaras képalkotó rendszerek mellett olyan új eszközök is megjelentek, mint a folyadékellenőrző, valamint a nyom- és szivárgásérzékelő müszerek. Ezek az eszközök használhatók a védett személyek, illetve a rendezvények biztosítása során is. Mindazonáltal a gyakorlati tapasztalatok azt mutatják, hogy önmagában egyetlen felderítési technika alkalmazása sem hozza meg a kívánt eredményt, és mivel a robbanóanyag-felderítés módszereinek és eszközeinek fejlesztése rendkívül összetett és időigényes folyamat, az eszközök és eljárásrendek együttes alkalmazása vált gyakorlattá. A biztonsági típusú felderítések során a technikai eszközök mellett a robbanóanyag-kereső kutyák továbbra is alkalmazásban maradtak.

\section{ÖSSZEGZÉS, KÖVETKEZTETÉSEK}

A katonák a müveleti területen, illetve a fegyveres konfliktusok területén élő emberek már régóta szembesülnek a robbanószerkezetek fenyegetéseivel. A technika fejlődésével a robbanószerkezetek nem tüntek el a harctérről, sőt egyre változatosabbak és kifinomultabbak lettek. A nemzetközi szervezetek sokéves erőfeszítései által létrehozott egyezmények kissé csökkentették, illetve szigorúan szabályozott keretek közé szorították a legveszélyesebb eszközök gyártását és felhasználását, de még mindig a legolcsóbb fegyverek egyike az akna, amely a hadiiparnak remek üzletet is jelent. Minderre és az elmúlt évtizedekben megerősödö terrorizmusra válaszul a robbanószerkezetek felderítéséhez használt eszközök és az alkalmazott módszerek is jelentősen megváltoztak, folyamatosan korszerüsödnek.

A tanulmányban igyekeztünk bemutatni a robbanószerkezetek felderítéséhez használt eszközök és módszerek fejlödésének történetét, illetve azok alkalmazási elveit. Megállapítható, hogy a robbanószerkezetek és a felderítésükhöz szükséges eszköztár folyamatosan egymással szoros párhuzamban fejlödik, és az egyre modernebb eszközök mindinkább elösegítik a biztonságos feladat-végrehajtást.

\section{FELHASZNÁLT IRODALOM}

1997. évi CXXXIII. törvény a „Mértéktelen sérülést okozónak vagy megkülönböztetés nélkül hatónak tekinthető egyes hagyományos fegyverek alkalmazásának betiltásáról, illetőleg korlátozásáról" szóló egyezmény és a hozzá csatolt jegyzőkönyvek kihirdetéséröl rendelkező 1984. évi 2. törvényerejü rendelet módosításáról és kiegészítéséről, 2. cikk, 4. Kihirdetve: 1997. XII. 10. https://net.jogtar.hu/ getpdf?docid=99700133.TV\&targetdate $=20070701 \&$ printTitle $=1997 .+\% \mathrm{C3} \%$ A9vi + CXXXIII. $+\mathrm{t} \% \mathrm{C} 3$ \%B6rv\%C3\%A9ny\&referer=http\%3A//net.jogtar.hu/jr/gen/hjegy_doc.cgi\%3Fdocid\%3DA1200100.TV A Guide to Mine Action, 2. edition. Geneva International Centre for Humanitarian Demining, Geneva, 2004. AJP-3.15 Allied Joint Doctrine for Countering Improvised Explosive Devices, NATO Standardization Office, 2018, 1-6.

ATP-3.12.1.3, Allied Tactical Doctrine for Route Clearance, Edition A, Version 1, NATO Standardization Office (NSO), 2016.

Biological Method (Bees) for Explosive Detection. NATO E-Library, 17. 03. 2020. https://www.spsbees4exp.com/

Bucsák Mihály - Csurgó Attila - Horváth Tibor - Láng László - Molnár Sándor - Posta Lajos - Szatai Zsolt - Vörös Mihály: 70 év az életveszély árnyékában. A magyar tüzszerész- és aknakutató alakulatok története 1945-2015. Zrínyi Kiadó, Budapest, 2015. 
DIM na BRDM2. https://www.mycity-military.com/slika.php?slika=192952_162477311_DIM\%20 na\%20BRDM2.jpg

Falkland's Demining Project fourth phase draws to a close. MercoPress, 24. 02. 2016. https://en.mercopress. com/2016/02/24/falkland-s-demining-project-fourth-phase-draws-to-a-close

FM 5-31 - Booby Traps. Department of the Army, Washington D.C., 14. 09. 1965. http://everyspec. com/ARMY/FM-Field-Manual/FM_5-31_13829/

FMFRP 12-43, Professional Knowledge Gained from Operational Experience in Vietnam, 1969, Special Issue, Mines and Boobytraps. Department of the Navy, Headquarters United States Marine Corps, Washington DC., Section I, 20. 07. 1989. https://fdocuments.in/download/?url=ele7afa8cc6f80e368 6134ef9fb85420461bc79b935935d8b72b5ff63443bf64b2235a042c643df0280bdf71b64cd47a6d58c9 e87a86a5b79568c0c85bfc0127BUzj5jb+Xhc/Em9g8FumPQKzwe3L3hY5ZRxB2C7V2ibrU0X/BD $\mathrm{x} 0 \mathrm{Z} 5 \mathrm{Lcuc}+\mathrm{ksaB}+\mathrm{jMjdrBlo16bjPMXCS} 8 \mathrm{wW} 2 \mathrm{~g}==$

GAO-02-1003 U.S. Use of Land Mines in the Persian Gulf War. United States General Accounting Office, Washington, DC, 09. 2002. https://www.gao.gov/assets/240/235830.pdf

Görög István - Padányi József: Az IFOR-SFOR Magyar Müszaki Kontingens 1996-2002. Zrínyi Kiadó, Budapest, 2005.

Horváth Tibor: Emergency Cases at Countering Improvised Explosive Devices, and their Potential Management. Revista Academiei Fortelor Terestre / Land Forces Academy Review, XXIV. No. 2, 27. 07. 2019. https://content.sciendo.com/view/journals/raft/24/2/article-p95.xml?lang=de\&result=9\& rskey=PzmED8, DOI: 10.2478/raft-2019-0011

Horváth Tibor: Magyarország akna- és löszermentesitésének története. A kezdetek 1944-1948. Müszaki Katonai Közlöny, XXVIII. évf. 2018/1., 68-75. https://mkk.uni-nke.hu/document/mkk-uni-nke-hu/ 2018_1_07_Horvath\%20T_Aknamentesites_MKK.pdf

Husky Vehicle Mounted Mine Detection System. Military.com. https://www.military.com/equipment/ husky-vehicle-mounted-mine-detection-system

Landmine Monitor Report 1999, Toward a mine-free world. Human Right Watch, New York, 1999.

Landmines, Explosive Remnants of War and IED Safety Handbook, 3rd edition. United Nations Mine Action Service (UNMAS), New York, 2015. https://www.unmas.org/sites/default/files/ handbook_english.pdf

Lukács László: A föld akna-problémája és a megoldás lehetöségei, különös tekintettel a Magyar Honvédség közremüködésének javasolható irányaira III. Müszaki Katonai Közlöny, VIII. évf. 1998/3-4., 3-22. https://mkk.uni-nke.hu/document/mkk-uni-nke-hu/1998_3_4\%2002\%20F\%C3\%B61d\%20 aknaprobl\%C3\%A9m\%C3\%A1ja\%20-\%20Luk\%C3\%A1cs\%20L.pdf

Lukács László: Kis akna történelem. Nemzetvédelmi Egyetemi Közlemények, 6. évf. 2002/3., 29-37. Mueller Othmár: Korszerü szükséganyagból készitett robbanószerkezetek alkalmazásának és hatástalanitásának sajátosságai, a jövőbeni fejlesztés irányai a terrorizmus figyelembevételével. Kandidátusi értekezés, 1995.

Padányi József: A menekültek és hontalanok visszatelepítése Bosznia-Hercegovinába. Hadtudomány, X. évf. 2000/2. http://mhtt.eu/hadtudomany/2000/2_13.html

Science for Peace and Security Programme. https://www.nato.int/cps/en/natohq/topics_85373.htm

Szabó Sándor - Kovács Tibor - Kovács Zoltán: Az utak, területek akadálymentesitése I. (ROUTE CLEARANCE). Müszaki Katonai Közlöny, XXIV. évf. 2014/3., 15-29. https://nkerepo.uni-nke. hu/xmlui/bitstream/handle/123456789/13899/Az\%20utak,\%20ter\%C3\%BCletek\%20akad\%C3 \%A1lymentes\%C3\%ADt\%C3\%A9se\%20I..pdf?sequence=1

Szatai Zsolt József: A fémtartalmú robbanószerkezetek felderitéséhez alkalmazott technikai eszközök. Müszaki Katonai Közlöny, 29. évf. 2019/1., 121-138. http://real.mtak.hu/104129/1/mkk_2019_1_10. pdf, DOI: $10.32562 / \mathrm{mkk} \cdot 2019.1 .10$ 
Афганские фотографии солдат советской армии. Афганистан - как это было (цветные фото).

Kollege, 15. 07. 2019. https://kollege.ru/sochineniya/afganskie-fotografii-soldat-sovetskoi-armiiafganistan-kak-eto.html

Провин, Павел: История создания металлоискателей: отечественное развитие. Часть 3. 22. 05.

2017. https://www.mdregion.ru/o-kladoiskatelstve/28-rasskazi-kladoiskatelstvo/3475-istoriasozdania-metalloiskatelei-chast-3.html

\section{A ZRTNVIRADO AJANLATA}

A négykötetes Magyarország hadtörténete harminc év elteltével mutatja be újra - a korábbi összefoglalóktól némileg különböző korszakolással és eltérő hangsúlyokkal - 1100 éves hadi históriánkat. A kötetekben a legújabb kutatási eredmények szintézise olvasható, amely korszerü tematika szerint tárgyalja az egyes korszakok hadügyi struktúráját és intézményeit.

\section{MAGYARORSZÁG HADTÖRTÉNETE I. \\ A KEZDETEKTÖL 1526-IG}

Az első kötet a középkor hadtörténetét tárgyalja a római időszaktól kezdődően, amikortól a Kárpát-medence mindmáig hatóan bekerült a nyugati világba, egészen a mohácsi csatáig. Ugyanakkor az összefoglaló igyekszik a korábbiaknál sokkal szervesebben bemutatni a megújuló történeti földrajzi, vár- és fegyverzettörténeti kutatások eredményeit. A könyvet mintegy 300 kép és térkép illusztrálja.

\section{MAGYARORSZÁG HADTÖRTÉNETE II. AZ OSZMÁN HÓDÍTÁS KORA 1526-1718}

A második kötet Magyarország, pontosabban a Magyar Királyság, az Erdélyi Fejedelemség és az oszmán hódoltsági területek 1526 és 1718 közötti hadtörténetéről szól. Az időhatárokat a mohácsi csata és a pozsareváci béke, vagyis az oszmán hódítás kezdete, illetve a királyság utolsó területeinek török uralom alóli felszabadítása adja.
MAGYARORSZÁG HADTÖRTÉNETE III. MAGYARORSZÁG A HABSBURG MONARCHIÁBAN 1718-1919

A sorozat harmadik kötete azt az időszakot mutatja be, amelynek során Magyarország területe teljes egészében a Habsburgok dunai monarchiájának része volt. A korszak nemcsak háborúkról szól, hanem - többek között - a hadseregek felépítéséről, fegyvertörténetről, katonai jelképekről és egyenruha-történetről is. Mindezt teszi sok térképpel és képpel illusztrálva.

\section{MAGYARORSZÁG HADTÖRTÉNETE IV. 1919-TÖL NAPJAINKIG}

A gazdagon illusztrált kötetben az időrendben öszszefoglalt hadtörténeti események mellett helyet kapott sok más téma is: a hadseregek felépítése, ellátása, felső vezetése, a hadkiegészítés rendszere, illetve a fegyvertörténet, az egyenruhák, kitüntetések és zászlók története.

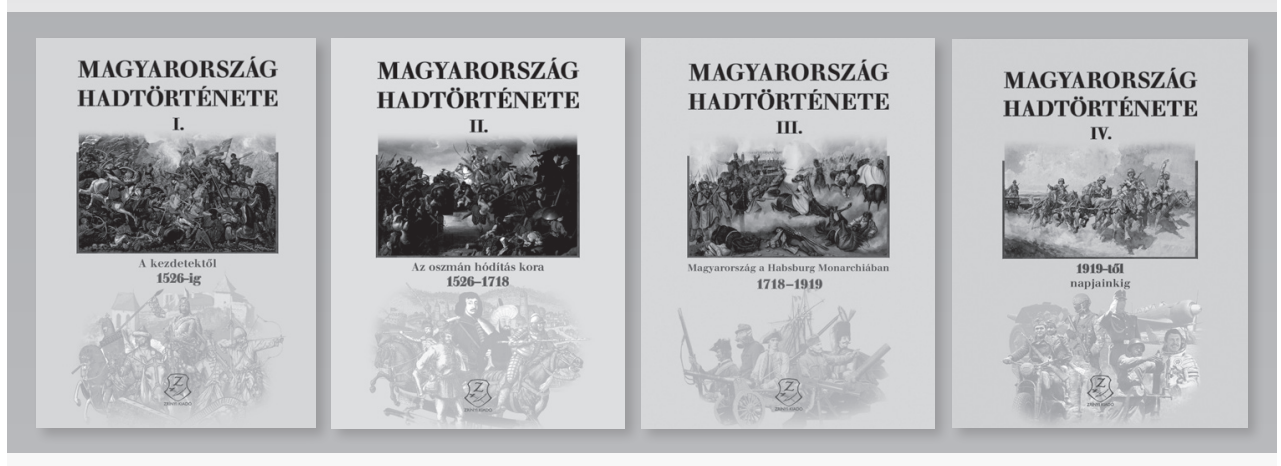

A kötetek megvásárolhatók a Zrínyi Kiadó webshopjában (https://shop.hmzrinyi.hu/) vagy a Kiadó könyv- és térképboltjában (1024 Budapest, Fillér u. 14.). 